\section{Choline Acetylase in the Human Placenta at Different Stages of Development}

Ir has long been known that there is acetylcholine in the human placenta ${ }^{2}$ and Comline's ${ }^{2}$ experiments established that choline acetylase, the enzyme which synthesizes acetylcholine, is in the placenta as well. The rate of acetylcholine synthesis, which he observed in extracts of acetone powders, made from mature placentæ, was between 0.6 and $0.75 \mathrm{mgm} . / \mathrm{gm}$. acetone-dried tissue/hr. Later in this laboratory, when a coupled enzyme system was used to provide an independent supply of the substrate acetylco-enzyme $A$, rates of 5-6 mgm./gm./hr. were obtained ${ }^{3}$.

More recently we have re-measured the choline acetylase activity in mature and in some early placentæ (at 15, 24, 25 and 34 weeks of development) and have found that the choline acetylase activity of the early placentæ is higher than of those which reach term. But the activity even in the fully developed placentæ may be much greater than that reported earlier. Expressed (in terms of the chloride) as the amount of acetylcholine produced per $\mathrm{gm}$. acetone powder, por $\mathrm{hr}$., rates as high as $34 \mathrm{mgm}$. have beon observed. Neither the foetal blood nor the other foetal membranes (amnion, umbilical cord) have any significant activity and the placental tissue washed free of blood is found to synthesize acetylcholine at the same or little higher rate than samples that contain blood. In this respect the enzyme differs from placental cholinesterase, since it appears from

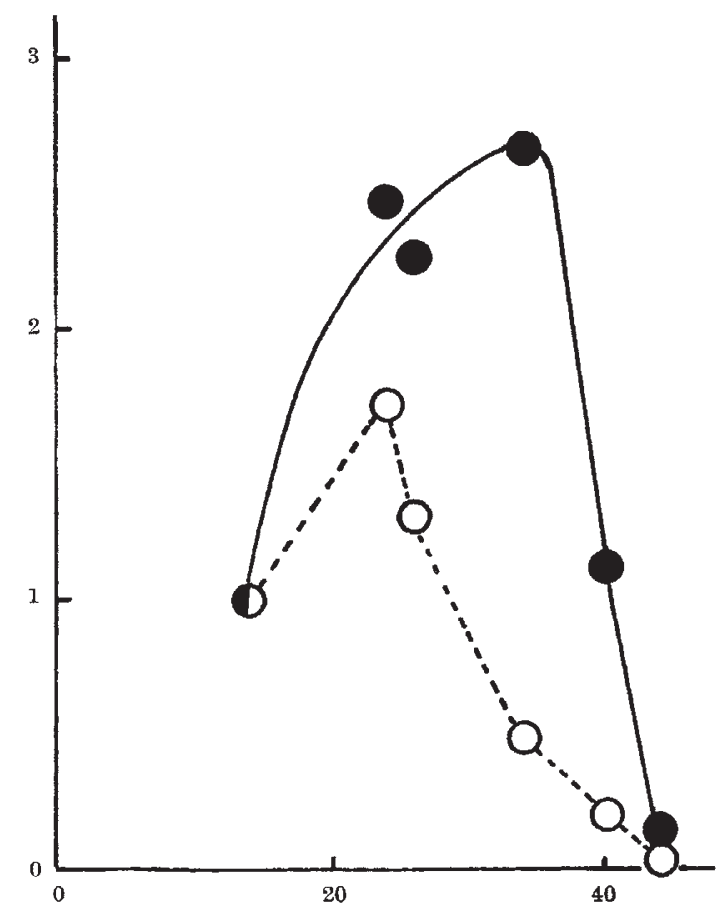

Fig. 1. Choline acetylase activity of the human placenta at different stages of development. The activity is determined by measuring the amount of acetylcholine produced by incubating an extract of a known quantity of tissue (equivalent to $1 \mathrm{mgm}$. O more) for $1 \mathrm{hr}$. at $38.5^{\circ} \mathrm{C}$. in a system containing coenzyme $A$, acetylphosphate, phosphotransacetylase, choline, $l$-cysteine, potassium chloride, magnesium chloride, eserine sulphate and sodium phosphate buffer ( $p \mathrm{H}$ 6.9). The ordinate is the amount of acetylcholine expressed as gm. acetylcholine-chloride and the abscissa is the developmental age of the placenta in weeks. $O$, activity per $100 \mathrm{gm}$. of tissue; , activity per total weight
Ord and Thompson 4 that cholinesterase of the placental tissue and of the blood which it contains is about equal.

By comparison with the mature placentæ those in which development had been interrupted at an early stage had extraordinarily high concentrations of choline acetylase. The highest activity was exhibited by a placenta thought to be 24 weeks old. Acetone powders made from this specimen had an average activity of $130 \mathrm{mgm}$. acetylcholine-chloride/gm./hr., equivalent to $17.1 \mathrm{mgm}$./gm. fresh tissue and a total activity for the whole organ of about $2 \cdot 0 \mathrm{gm} . / \mathrm{hr}$. The specific activity of the extracts, or the amount of acetylcholine formed per $\mathrm{mgm}$. of protein was $7 \cdot 6 \mu \mathrm{M}$. So far as we are aware, this is the highest activity yet reported for any vertebrate tissue.

Fig. 1 shows how both concentration and total activity vary during development of the placenta. Although, as already mentioned, the concentration was highest at 24 weeks, the total amount was higher in the 34-week placenta. This suggests that the tissue containing the enzyme continues to grow for the first 24-34 weeks; but that some time before 34 weeks its growth is overtaken by the growth of other tissue elements with the consequence that its concentration falls. At the end of pregnancy, however, there is a decrease both in concentration and total amount of choline acetylase. This might be due either to involution and degeneration of the tissue containing the enzyme, or its denaturation. We have some evidence to suggest that this might occur by oxidation of its sulphydryl groups.

The results are of interest in that they strengthen the view that acetylcholine is of importance in placental function during pregnancy. Present indications are that the enzyme is located in the chorionic villi, in the cell layers separating maternal from foetal blood. We are tempted to suggest therefore that its function is in the active transport of materials across this barrier.

We are grateful to Dr. J. Dickie at the County Maternity Hospital, Cambridge, for enabling us to obtain the placentæ and providing the clinical history of each.

\section{Gordon BuLL} Catherine HebB

DoBrilla RATKovió*

Institute of Animal Physiology, Agricultural Research Council, Babraham, Cambridge.

* Wellcome Research Fellow.

${ }^{2}$ Haupstein, P., Arch. Gynäk., 151, 262 (1932). Chang, H. C., and Gaddum, Jै. H., J. Physiol., "79, 255 (1933).

${ }^{2}$ Comline, R. S., J. Physiol., 105, 6 P (1946).

3 Hebb, C. O., Physiol. Rev., 37, 196 (1957).

' Ord, M. G., and Thompson, R. H. S., Nature, 165, 927 (1950),

\section{Effect of Dimethyl Sulphoxide on the Cryo-tolerance of Mitochondria}

THe integrated structural and functional complexes of many biological entities have been conserved by freezing and storage at low temperatures. The cryotolerance of enzymes, viruses, bacteria, cells or tissues has been increased by the inclusion of "protective substances' in the suspending medium ${ }^{1,2}$. We have reported recently the role of glycerol in protecting oxidative phosphorylation by suspensions of mitochondria during freezing or freezing and storage at low temperatures ${ }^{3}$. Dr. Audrey Smith, of the National Institute for Medical Research, London, suggested to 